\title{
Entrepreneurial Intentions of Students in Poland in the View of Ajzen's Theory of Planned Behaviour
}

\author{
Krzysztof Wach, Liwiusz Wojciechowski
}

\section{A B S T R A C T}

Objective: The purpose of this study is to empirically verify Ajzen's theory in the Polish academic environment, however, the TPB was extended by one more variable - attitude towards risk.

Research Design \& Methods: We decided to use a survey questionnaire among students. The survey was conducted among seven universities in Krakow. Out of 1,100 sent questionnaires, we received 719 fully completed and corrected questionnaires, it means that the return rate is $65.4 \%$. The questionnaire was divided into 14 thematic blocks - their elements explain the entrepreneurial intentions.

Findings: The statistical calculations confirmed that three Ajzen's independent variables, such as attitude towards entrepreneurship, subjective norms and perceived behavioural control determine the entrepreneurial intentions of the investigated students. Additionally, we found out that the risk attitude is also a determinant in a similar way, and entrepreneurial intentions differ between business and nonbusiness students.

Implications \& Recommendations: Shaping the entrepreneurial mindset of young people is one of the most important roles of the contemporary education system, including the tertiary education. Future studies should seek new factors influencing the entrepreneurial intentions of students, facts that will be complementary to TPB and EEM models.

Contribution \& Value Added: The study extended Ajzen's TPB of risk propensity as a separate variable describing the attitude towards entrepreneurship.

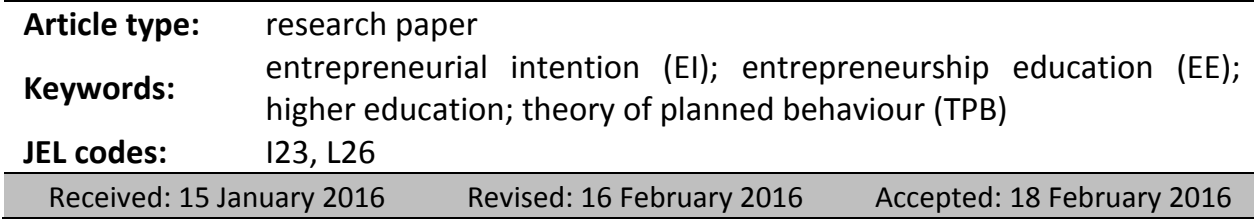

\section{Suggested citation:}

Wach, K., \& Wojciechowski, L. (2016). Entrepreneurial Intentions of Students in Poland in the View of Ajzen's Theory of Planned Behaviour. Entrepreneurial Business and Economics Review, 4(1), 8394, DOI: http://dx.doi.org/10.15678/EBER.2016.040106 


\section{INTRODUCTION}

Intention-based models, although derived from social psychology, are used successfully in management research, especially in the study of entrepreneurship. On this basis, one can predict future behaviour, which is important for both managers, economic analysts and policy makers responsible for the creation of an appropriate entrepreneurship support system, including its important element which is entrepreneurship education (Wach, 2013; 2014; 2015) whose main task is to develop appropriate entrepreneurial attitudes. A suitable educational system stimulating entrepreneurship is important for economic practice. For many years such solutions have been recommended by the European Union (Wach, 2014b; Najda-Janoszka \& Wach, 2008), but also in Poland the implementation of these recommendations is gaining in importance, not only in the business school (Kosała \& Pichur, 2008), but also in non-economic fields of studies (Płaziak \& Rachwat, 2014), especially in the context of the internationalisation and Europeanisation of Polish universities (Marona \& Głuszak, 2014). The contemporary task of the university is to develop entrepreneurial attitudes and to inspire creative thinking (Żur, 2014), as well as to awaken entrepreneurial intentions among students (Kuehn, 2008). Entrepreneurship education is not only important in the development of entrepreneurial attitudes, but in stimulating entrepreneurship in general (Daszkiewicz, 2014; Urbaniec, 2014), and especially in the family business (Rachwat, 2010).

The purpose of this study is to empirically verify Ajzen's theory of planned behaviour (TPB) in Polish realities, however, we extended the TPB by one more variable - attitude towards risk. In the study we used a questionnaire survey conducted among students of seven different universities in Krakow, including both economic and non-economic fields of studies, as well as of different years $(n=719)$.

The first section of the paper includes the literature review on entrepreneurial intentions from the perspective of behavioural sciences. The second section discusses the methodological assumptions of the empirical studies, among them the hypotheses, the research design and the sampling. The third section elaborates on the empirical results of the survey and the statistical calculations, followed by the conclusions in a typical layout consisting of final remarks, research limitations and suggestions for further studies.

\section{LITERATURE REVIEW}

To understand what mechanisms govern the entrepreneurial intentions of individuals, usually various researchers take advantage of a well-established psycho-sociological concept originated in the mid-1980s - namely, the theory of planned behaviour developed by Ajzen (1987, 2011). According to this theory, behavioural intentions depend on three antecedents (i), that is the attitude towards a given behaviour, (ii) the perceived behavioural control, sometimes called feasibility, and (iii) social norms that shape the perception of such a behaviour. The first two factors (i.e. the attitude toward the behaviour, but rather the attitude towards the results associated with the behaviour and the perceptions of social norms with respect to this behaviour) reflect the desirability and the desired occurrence of such a behaviour. The third factor reflects the personal perception of the ability to control the behaviour and is usually called self-efficacy. 
TPB is one of the most popular concepts while studying entrepreneurial intentions (Karimi et al., 2016; Piperopoulos \& Dimov, 2015; Lima, Lopes, Nassif \& de Silva, 2015). There is no clear and universal definition of an entrepreneurial intent in the literature. Thompson (2009, p. 676) defines an individual entrepreneurial intent or an entrepreneurial intention as "a self-acknowledged conviction by a person that they intend to set up a new business venture and consciously plan to do so at some point in the future". Intention among potential entrepreneurs is seen as a "conscious state of mind that precedes action" (Shook, Priem \& McGee, 2003, p. 380). This general concept of the intentional behaviour is very popular among researchers analysing entrepreneurial intentions. Similarly, Krueger (1993) defines entrepreneurial intentions as the tendency to have the potential to start your own business in the near future. Koçoğlu and Hassan (2013) emphasise that entrepreneurial intentions depend indeed on three above mentioned variables (attitude towards entrepreneurship, subjective norms, perceived behaviour control), but in addition, they also depend on personal factors, mainly on how a person perceives their present conditions and the possibilities leading to a desired state (Azjen, 1987, 1991; Retan, 1997). Byabashaija and Katono (2011), but also Bae at al. (2014) emphasise a particular role of situational factors (such as employability and the ability to make sacrifices and liabilities), as well as personality features (such as desirability, feasibility, effectiveness), which promote entrepreneurial intentions and their conversion to specific behaviour, in other words to set up your own business.

The second also frequently cited theoretical conceptualisation of entrepreneurial intentions is the entrepreneurial event model (EEM), often referred to as the concept of SEE (Shapero's entrepreneurial event), as this concept was initially created by Shapero (1975), and then developed by him together with his colleagues (Shapero \& Sokol, 1982), although Krueger (1993) contributed to the development of this framework by introducing external factors, thus, this concept is sometimes referred to as the Shapero-Krueger model (Krueger, Carsrud, \& Reilly, 2000). Shapero's model assumes that inertia drives human activity, until there is an action disturbing the balance that usually has a negative context (e.g. loss of a job). Such impulses force a person to act (Heuer, 2012). Apart from entrepreneurial intentions, the credibility of a behaviour is also very important. Credibility is understood dichotomously as desirability and feasibility. These factors shape entrepreneurial intentions. An individual entrepreneurial intent is shaped in a broader context, it is to take into account a number of factors, both personal and behavioural (Elfving et al., 2009).

The theory of planned behaviour (TPB) and the entrepreneurial event model (EEM) are "the two most extensively tested competing theories that have been used to explain entrepreneurial intention" (Schlaegel \& Koenig, 2013, p. 292). The co-creator of the latter concept also thinks so (Krueger et al., 2000). Intention-based models are implemented successfully not only in social psychology, but also in marketing and management (Krueger, Reilly, \& Carsrud, 2000, p. 416).

Prior research revealed very interesting empirical conclusions. Schlaegel and Koenig (2013, p. 318) studying all the determinants indicated in the TPB and EEM models showed "that the different determinants included in the two theories have a positive effect on entrepreneurial intentions". Pfeifer, Šarlija, and Zekić Sušac (2016) found that the main predictors of entrepreneurial intentions in Croatia are the strength of entre- 
preneurial identity aspiration and entrepreneurial self-efficacy. Siger and Monsen (2015) found that young people across various European countries perceive academic employment as an intrapreneurial career path (Perlman, Gueths \& Weber, 1988), thus, the investigated "students with high levels of entrepreneurial self-efficacy prefer the academic to the employment option and the founding to the academic option" (Siger \& Monsen, 2015, p. 45).

\section{MATERIAL AND METHODS}

The aim of the empirical research was an attempt to implement the theory of planned behaviour of Ajzen $(1987,1991,2011)$ among a group of students in the Polish academic environment. It is one of the most widely used concepts in analysing the intentions of behaviour, especially entrepreneurial intentions worldwide, and recently this concept is also implemented in Poland (Claar et al., 2012; Jiménez-Moreno \& Wach, 2014; Wach, 2015; Rantanen, Pawlak \& Toikko, 2015; Rachwał \& Wach, 2016).

We decided to use a survey questionnaire among students. The survey was conducted by the Centre of Strategic and International Entrepreneurship of the Cracow University of Economics and the questionnaire was developed by Krzysztof Wach as a leader of the research project (Entrepreneurial Intentions Questionnaire, EIQ). However, it was based on the original questionnaires used in TPB and EEM surveys, nevertheless, they were extended and adapted to Polish realities.

The EIQ 2015 survey was conducted in a couple of universities in Krakow, including ${ }^{1}$ : (i) Cracow University of Economics, (ii) Jagiellonian University, (iii) Pedagogical University of $\mathrm{Cracow}^{2}$, (iv) AGH University of Science and Technology, (v) Cracow University of Technology, (vi) University of Agriculture in Krakow, (vii) Jesuit University Ignatianum in Krakow.

The Centre of Strategic and International Entrepreneurship prepared 1100 questionnaires and sent them to randomly selected professors from seven various universities in Krakow, asking them to distribute the questionnaires among their students during classes. Finally, we received 719 fully completed and corrected questionnaires, it means that the return rate is $65.4 \%$.

The questionnaire consisted of 14 thematic blocks (A: Entrepreneurial intention El; B: Attitude towards becoming an entrepreneur; C: Attitude towards entrepreneurial risk; D: Subjective norms; E: Entrepreneurial capacity; F: Entrepreneurial self-efficacy ESE; G: Entrepreneurial education EE; H: Perceived support; I: Perceived barriers; J: Locus of control; K: Proactive personality; L: Individual innovativeness; M: Entrepreneurial objectives; N: Characteristics of respondents). These blocks consisted of 3-20 specific questions, evaluated subjectively by the respondent on a 7-point Likert's scale. Where it was justified (A-L), we transformed the variables of individual blocks into quasi-continuous data using the arithmetic mean (Allen \& Seaman, 2007), giving the image of a given trait of individuals. The survey was conducted from January to June 2015, and was followed by the construction of the database, the analyses of the correctness and completeness of the collected statistical data.

\footnotetext{
${ }^{1}$ The official names of these universities were used (Krakow vs. Cracow).

${ }^{2}$ The results of the survey at that university are published in Rachwał \& Wach (2016).
} 
The following research hypotheses were assumed to be verified based on the empirical material:

H1: Attitude (Ajzen's TPB): The individuals positively disposed towards entrepreneurship are characterised by significantly higher entrepreneurial intentions than those reluctant to entrepreneurship.

H2: Risk (extension of Ajzen's model): The higher the willingness of individuals to take the risk, the higher the entrepreneurial intentions.

H3: Norms (Ajzen's TPB): The higher subjective standards to private enterprise in the society, the higher the entrepreneurial intentions of the individual.

H4: Control (Ajzen's TPB): The higher the belief in a possible control over the potential business activity is, the higher the entrepreneurial intentions of the individual.

In order to verify the hypotheses we used descriptive statistics, correlation analysis and multivariate analysis. The calculations were performed in the environment of MS Excel and Stata 12.

\section{RESULTS AND DISCUSSION}

Based on the correlation analysis carried out for the full sample (Table 1), we found that students with a very positive attitude towards becoming an entrepreneur (B), assuming that being an entrepreneur has more advantages than disadvantages), have high entrepreneurial intentions (A), meaning that these students are ready to make a lot of efforts to start and run their own business $(r=0.8)$. Those students who are willing to start a business (A), and what is more it would be easy for them due to their entrepreneurial capacity (E), have a high sense of entrepreneurial self-efficacy (F). It is worth adding that these students at the same time declare relatively high ratings of their entrepreneurship education (G). We also noted that the proactive personality (K) accompanied the innovative behaviour of students (L). We found negative correlations between proactivity $(\mathrm{K})$ and innovative individual behaviour (L), as well as between a locus of control $(\mathrm{J})$ and individual innovativeness (L), which in the future should result in a in-depth analysis with regard to more homogeneous control variables.

It is visible that those students who plan to become entrepreneurs significantly stand out from the respondents in plus in terms of most of the criteria. In particular, these differences are visible in the case of the questions about entrepreneurial self-efficacy. In the case of the questions about a locus of control, a person willing to become an entrepreneur showed lower scores than the others (Figure 1), which means that these students believe that everything depends on them, not on luck.

By distinguishing the sample into two sub-samples (students that are studying on economic/business studies and others), we assume that these two groups differ significantly in some cases. Particularly, we observe big differences in the case of entrepreneurial intentions, entrepreneurial self-efficacy and entrepreneurship education. Those who study economics/business are characterised by higher average values of these variables (Figure 2).

According to the first regression model (Table 2), the higher attitude (B) towards 
becoming an entrepreneur (i.e. satisfaction, being one's own boss rather than having a secure job), the higher entrepreneurial intentions $(A)$ are.

Table 1. The correlation matrix of synthetic indicators designed on the basis of particular thematic blocks of questions $A-L$

\begin{tabular}{|c|c|r|r|r|r|r|r|r|r|r|r|r|}
\hline & A & B & C & D & E & F & G & H & I & J & K & L \\
\hline A & 1.00 & & & & & & & & & & & \\
\hline B & 0.80 & 1.00 & & & & & & & & & & \\
\hline C & 0.41 & 0.40 & 1.00 & & & & & & & & & \\
\hline D & 0.36 & 0.40 & 0.32 & 1.00 & & & & & & & & \\
\hline E & 0.59 & 0.55 & 0.47 & 0.41 & 1.00 & & & & & & & \\
\hline F & 0.43 & 0.42 & 0.39 & 0.36 & 0.67 & 1.00 & & & & & & \\
\hline G & 0.36 & 0.28 & 0.32 & 0.17 & 0.59 & 0.54 & 1.00 & & & & & \\
\hline H & 0.35 & 0.35 & 0.22 & 0.26 & 0.40 & 0.41 & 0.39 & 1.00 & & & & \\
\hline I & -0.20 & -0.19 & -0.16 & -0.16 & -0.30 & -0.21 & -0.22 & -0.12 & 1.00 & & & \\
\hline J & -0.18 & -0.15 & -0.22 & -0.18 & -0.24 & -0.24 & -0.21 & -0.09 & 0.30 & 1.00 & & \\
\hline K & 0.39 & 0.36 & 0.46 & 0.30 & 0.49 & 0.45 & 0.44 & 0.23 & -0.19 & -0.36 & 1.00 & \\
\hline L & 0.33 & 0.30 & 0.49 & 0.28 & 0.42 & 0.39 & 0.37 & 0.16 & -0.24 & -0.42 & 0.69 & 1.00 \\
\hline
\end{tabular}

Note: Critical level of Pearson correlation $0.052(\alpha=0.05)$.

Source: own calculations in Stata 12 (EIQ 2015, $n=719$ ).

Similar results were noted in the case of the attitude towards entrepreneurial risk (C). The more willing to take a risk, experience-oriented, courageous students are, the more often they state that their goal is to be an entrepreneur and to create their own business in future. Statistically significant and positive coefficient corresponding to (E) means that high entrepreneurial capacity influences entrepreneurial intentions.

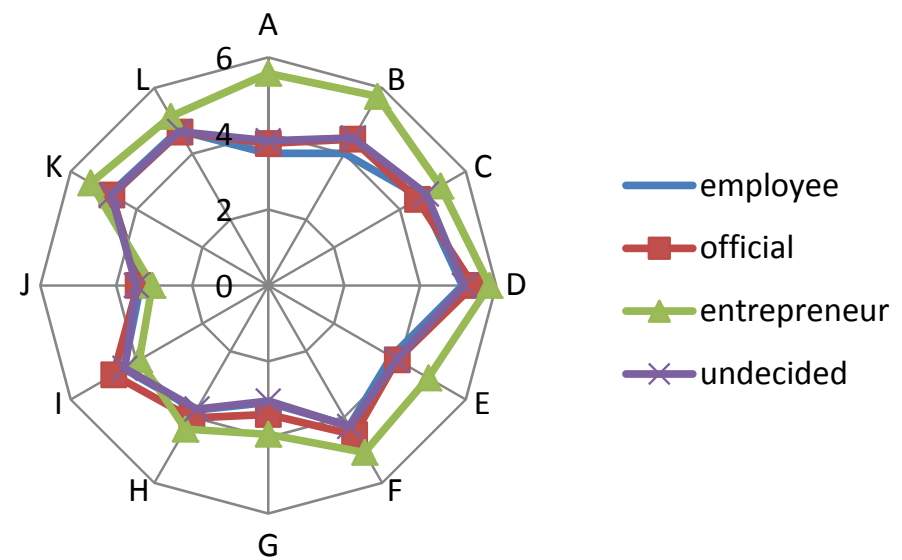

Figure 1. Radial diagram of the average values $A-L$ and the desired career path Source: own study (EIQ 2015, $n=719$ ). 
Moreover, controlling the education background by using Economic_studies variable $^{3}$, we assume that those who study economics/business have significantly higher entrepreneurial intentions than others. The presented model explains variance of $(\mathbf{A})$ in almost $70 \%$.

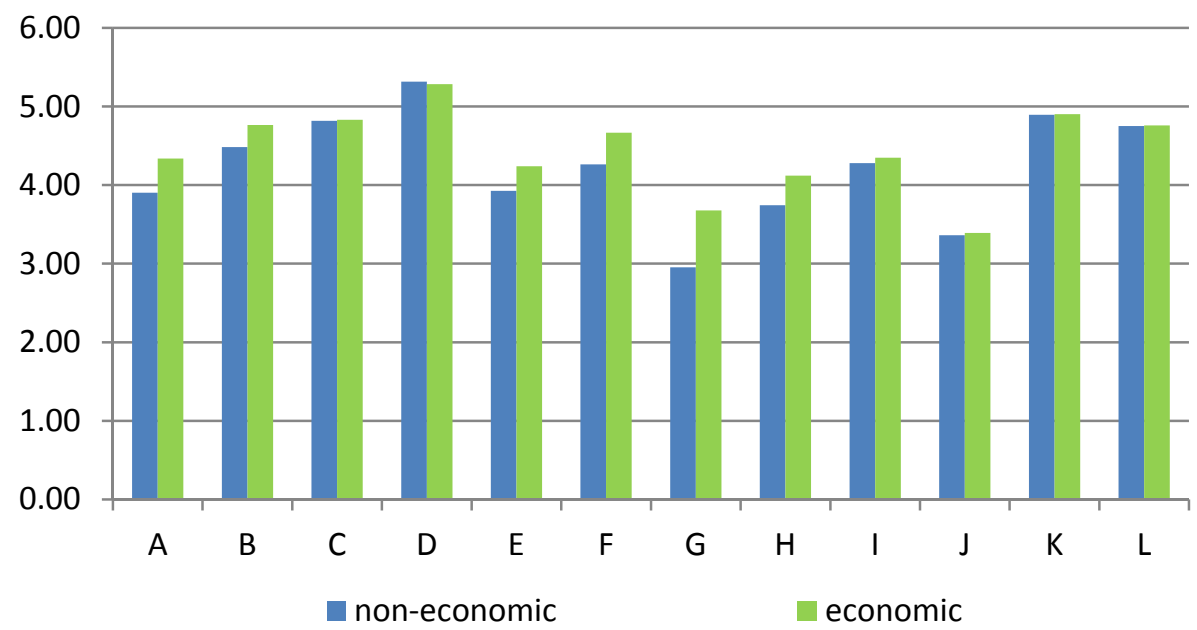

Figure 2. Bar diagram of the average values A-L by economic and non-economic studies Source: own study (EIQ 2015, $n=719$ ).

Table 2. The multiple OLS regression explaining entrepreneurial intention (version 1)

\begin{tabular}{|l|c|c|c|c|c|c|}
\hline dependent variable: A & coef. & st. err. & $t$-stat & $p$-value & \multicolumn{2}{|c|}{ conf. interval. } \\
\hline const & -0.795 & 0.179 & -4.430 & 0.000 & -1.147 & -0.443 \\
\hline B & 0.747 & 0.030 & 25.000 & 0.000 & 0.688 & 0.805 \\
\hline C & 0.085 & 0.034 & 2.470 & 0.014 & 0.017 & 0.152 \\
\hline D & -0.003 & 0.029 & -0.100 & 0.919 & -0.061 & 0.055 \\
\hline E & 0.244 & 0.036 & 6.840 & 0.000 & 0.174 & 0.314 \\
\hline Economic_studies & 0.147 & 0.063 & 2.350 & 0.019 & 0.024 & 0.270 \\
\hline Adj. R-squared & $67.3 \%$ & $\begin{array}{c}\text { F-stat \& } \\
p \text {-value }\end{array}$ & $\begin{array}{c}296.48 \\
{[0,000]}\end{array}$ & MSE & 0.826 & \\
\hline
\end{tabular}

Source: own calculations in Stata 12 based on EIQ 2015 survey $(n=719)$.

According to the second regression model (Table 3), these students who are more willing to take a risk, especially with regard to money, and who are looking for new experiences (C), aim to be entrepreneurs and to create their own businesses in future (A). We obtained similar results in the case of subjective norms (D). Students that claim that their family, friends and colleagues would admire their decision to start own business, have

\footnotetext{
${ }^{3}$ Binary variable: 1 if a respondent studies economics/business, 0 otherwise.
} 
higher entrepreneurial intentions. Statistically significant and positive coefficient corresponding to $(E)$ means that high entrepreneurial capacity influences entrepreneurial intentions. We also checked the education background as a control variable, as we assume also in this case that those who study economics/business have significantly higher entrepreneurial intentions than others. The presented model explains variance of $A$ in almost $40 \%$. Although this model explains rather low part of $A$ variance, it indicates that $D$ factor has got significant positive impact on the explained variable. In the first model this variable was omitted because of high correlation between $B$ and $D$ factors.

The results of our study are intuitive and in line with other research in this field. Karim et al. (2016, p. 195) using structural models, on a sample of 205 students from 6 Iranian universities, showed that there are positive effects of social norms, attitude towards entrepreneurship and perceived behavioural control on entrepreneurial intentions. Based on a sample of 454 students from one Croatian university, Pfeifer, Šarlija, and Zekić Sušac (2016, p. 108) found that entrepreneurial intentions are impacted mainly by entrepreneurial self-efficacy. Similar results were obtained by Piperopoulos and Dimov (2015, p. 970) using a sample of 114 students from major British universities, however, they evidenced that "higher self-efficiency is associated with lower entrepreneurial intentions in the theoretically orientated courses and higher entrepreneurial intentions in the practically orientated courses". We tested this issue in general, so it can beneficial to test also the impact of the course character (practical vs. theoretical).

\section{CONCLUSIONS}

The statistical calculations confirmed that three Ajzen's independent variables, such as attitude towards entrepreneurship, subjective norms and perceived behavioural control determine entrepreneurial intentions of the investigated students. Additionally, we found out that the risk attitude is also a determinant in a similar way, and entrepreneurial intentions differ between business and non-business students. All four hypotheses were confirmed. Based on the empirical material, we can draw the following detailed conclusions:

- There is a strong positive relationship between entrepreneurial intentions $(A)$ and attitude towards entrepreneurship (B), and moderately strong between entrepreneurial intentions $(A)$ and perceived behavioural control $(E)$.

- Students thinking of or planning to become entrepreneurs in the future are characterised by higher than in other groups variables such as attitude towards entrepreneurship (B), risk propensity (C), subjective norms (D), perceived behavioural control (E), entrepreneurial self-efficacy (F), and lower variables such as perceived barriers to entrepreneurship (I) and a locus of control (J).

- There are differences between students of economics/business and non-economic fields of studies. The differences manifest in particular in categories $A, B, F, G, H$, where individuals in the study fields of economics/business showed higher values.

- Estimated models indicate that the individual entrepreneurial intent is positively influenced by such factors as B, C, D, E, as well as the fact of being a student of economics/business study fields. 
Like any empirical studies based on perception, also the one presented and discussed in the article, has its research limitations. First, the sample was relatively large, but did not include the entire student population of Krakow, and the same was not fully representative, however, it was randomly selected. Second, statistical inferencing on the basis of perception, although fully acceptable by psychologists and having a lot of confirmations in fact, still does not allow to absolutise in entrepreneurship research. The collected empirical material and, above all the findings indicate a possible extension of the research by new research topics, such as positive and negative motives in making decisions about starting a business. In the next study it will be crucial to confront Ajzen's TPB with Shapiro's EEM, as well as to add new variables into these well-established models, such as proactiveness and innovativeness of individuals.

\section{REFERENCES}

Ajzen, I. (1987). Attitudes, traits, and actions: Dispositional prediction of behaviour in social psychology. Advances in Experimental Social Psychology, 20, 1-63.

Ajzen, I. (1991). The theory of planned behavior. Organizational Behaviour and Human Decision Processes, 50, 179-211.

Ajzen, I. (2011). The theory of planned behaviour: Reactions and reflections. Psychology \& Health, 26(9), 1113-1127, http://dx.doi.org/10.1080/08870446.2011.613995

Allen, I.E., \& Seaman, C.A. (2007). Likert scales and data analyses. Quality Process, 40(7), 64-65.

Bae, T.J., Qian, S., Miao, Ch., \& Fiet, J.O. (2014). The Relationship Between Entrepreneurship Education and Entrepreneurial Intentions: A Meta-Analytic Review. Entrepreneurship Theory and Practice, 38(2), 217-254.

Byabashaija, W., \& Katono, I., (2011). The Impact of College Entrepreneurial Education on Entrepreneurial Attitudes and Intention to Start a Business in Uganda, Journal of Developmental Entrepreneurship, 16(1), 127-144.

Claar, V.V., Frey, R., Szarucki, M., \& TenHaken, V.R. (2012). Hope for the East: entrepreneurial attitudes of MBA students in two transition economies relative to those in the USA. International Journal of Business Excellence, 5(3), 220-237.

Daszkiewicz, N. (2013), Education as a Stimulating Factor for Entrepreneurship Development. Horyzonty Wychowania, 13(26), 165-177.

Elfving, J, Brännback, M., \& Carsrud, A. (2009). Toward A Contextual Model of Entrepreneurial Intentions (chapter 2). In A.L. Carsrud, \& M. Brännback (Eds.), Understanding the Entrepreneurial Mind: Opening the Black Box (International Studies in Entrepreneurship Series, vol. 24). New York: Springer Verlag.

Heur, A. (2012). Perspectives on Parameters Influencing Entrepreneurial Intentions. Doctoral Dissertation. HEC Management School University of Liege, Liege.

Jiménez-Moreno, J.J., \& Wach, K. (2014). The Entrepreneurial Profile of Students Participating in the Academic Entrepreneurship Course: Pilot Study Results. Horyzonty Wychowania, 13(26), 121-143.

Karimi, S., Biemans, J.A.., Lans Th., Chizari, M., \& Mulder, M. (2016). Entrepreneurial Intentions and Opportunity Identification. Journal of Small Business Management, 54 (1), 187-209.

Koçoğlu, M., \& Hassan, M.U. (2013). Assessing Entrepreneurial Intentions of University Students: A Comparative Study of Two Different Cultures: Turkey and Pakistani, European Journal of Business and Management, 5(13), 243-252. 
Kosała, M., \& Pichur, A. (2008). Analiza działań przedsiębiorczych i postrzeganie prowadzenia działalności gospodarczej wśród młodego pokolenia - wybrane aspekty. Przedsiębiorczość Edukacja, 4, 347-354.

Krueger, N. (1993). Impact of prior entrepreneurial exposure on perceptions of new venture feasibility and desirability. Entrepreneurship Theory and Practice, 18(1), 5-21.

Krueger, N.F., Reilly, M.D., \& Carsrud, A.L. (2000). Competing models of entrepreneurial intentions. Journal of Business Venturing, 15(5-6), 411-432. http://dx.doi.org/10.1016/S08839026(98)00033-0

Kuehn, K.W. (2008). Entrepreneurial Intensions Research: Implications for Entrepreneurship Education. Journal of Entrepreneurship Education, 11, 87-98.

Lima, E., Lopes, R.M., Nassif V., \& de Silva, D. (2015). Opportunities to Improve Entrepreneurship Education: Contributions Considering Brazilian Challenges. Journal of Small Business Management, 53(4), 1033-1051.

Marona B., \& Głuszak M. (2014). The Ties that Bind? Real Estate Education in Europe and Regulatory Framework in Poland. The New Educational Review, 35(1), 187-201.

Najda-Janoszka, M., \& Wach, K. (2008). Lifelong Learning in the Field of Tourism in the European Union taking Poland into Special Consideration (pp. 45-58). In. M. Bednarczyk (Ed.), Entrepreneurship in Tourism and Sport Business. Kraków: Fundacja dla Uniwersytetu Jagiellońskiego.

Piperopoulos, P., \& Dimov, D. (2015). Burst Bubbles or Build Steam? Entrepreneurship Education, Entrepreneurial Self-Efficacy, and Entrepreneurial Intentions. Journal of Small Business Management, 53(4), 970-985.

Perlman, B., Gueths, J., \& Weber, D.A. (1988). The Academic Intrapreneur: Strategy, Innovation, and Management in Higher Education. New York: Praeger.

Pfeifer, S., Šarlija, N., \& Zekić Sušac, M. (2016). Shaping the Entrepreneurial Mindset: Entrepreneurial Intentions of Business Students in Croatia. Journal of Small Business Management, 54 (1), 102-117.

Płaziak, M., \& Rachwał, T. (2014). Entrepreneurship Courses in Spatial Management Studies in Polish Universities. Procedia - Social and Behavioral Sciences, 110, 710-718, http://dx.doi.org/10.1016/j.sbspro.2013.12.915

Rachwał, T. (2010). Entrepreneurship Education as a Growth Stimulus for Family Firms (chapter 9). In A. Surdej, \& K. Wach (Eds.), Exploring the Dynamics of Entrepreneurship (pp. 139-156). Toruń: Marszałek Publishing House.

Rachwał, T., \& Wach, K. (2016). Badanie intencji przedsiębiorczych młodego pokolenia: wyniki ankietyzacji wśród studentów kierunków nieekonomicznych. Przedsiębiorczość - Edukacja, 12.

Rantanen, T., Pawlak A., \& Toikko, T. (2015). The Significance of Social Welfare Attitudes in Young People's Entrepreneurial Intentions. Entrepreneurial Business and Economics Review, 3(1), http://dx.doi.org/10.15678/EBER.2015.030104

Schlaegel, Ch., \& Koenig, M. (2014). Determinants of Entrepreneurial Intent: A Meta-Analytic Test and Integration of Competing Models. Entreprenership Theory and Practice, 38(2), 291-332.

Shapero, A. (1975). The displaced, uncomfortable entrepreneur. Psychology Today, 9, 83-88.

Shapero, A., \& Sokol, L. (1982). Social dimensions of entrepreneurship. In C.A. Kent, D.L. Sexton, \& K.H. Vesper (Eds.), The encyclopedia of entrepreneurship (pp. 72-90). Englewood Cliffs, NJ: Prentice-Hall.

Shook, C.L., Priem, R.I., \& McGee, J.E. (2003). Venture creation and the enterprising individual: A review and synthesis. Journal of Management, 29(3), 379-399. 
Sieger, P., \& Monsen, E. (2015). Founder, Academic, or Employee? A Nuanced Study of Career Choice Intentions. Journal of Small Business Management, 53(1), 30-57.

Thompson, E.R. (2009). Individual Entrepreneurial Intent: Construct Clarification and Development of an Internationally Reliable Metric. Entrepreneurship Theory and Practice, 3(33), 669-694.

Urbaniec, M. (2014). Współczesne wyzwania edukacji na rzecz przedsiębiorczości w szkolnictwie wyższym. Horyzonty Wychowania, 13(26), 209-230.

Wach, K. (2013). Edukacja na rzecz przedsiębiorczości wobec współczesnych wyzwań cywilizacyjnogospodarczych. Przedsiębiorczość - Edukacja, 9, 246-257.

Wach, K. (2014). Europeanisation of Entrepreneurship Education in Europe - Looking Back and Looking Forward. Horyzonty Wychowania, 13(26), 11-32.

Wach, K. (2015). Środowisko biznesu rodzinnego jako stymulanta intencji przedsiębiorczych młodzieży akademickiej. Przedsiębiorczość i Zarzq̨dzanie, XVI(7[III]), 25-40.

Żur, A. (2014). Exploring the Role of Inspiration in Entrepreneurship Education. Horyzonty Wychowania, 13(26), 179-194. 


\section{Authors}

The contribution share of authors is equal and amounted to $50 \%$ each of them.

\section{Krzysztof Wach}

Associate Professor (Prof. UEK) of the Cracow University of Economics (Poland). Habilitated doctor of economics (DEcon), PhD in management, specialist in international entrepreneurship, author of several books and over 150 scientific articles, editor-in-chief of the scientific quarterly 'Entrepreneurial Business and Economics Review', member of editorial boards of several scientific journals, including 'Business Excellence' (Croatia), 'Studia Negtia' (Romania), 'Entrepreneurship - Education' (Poland); in the years 2012-2014 an OECD and the European Commission national expert for entrepreneurship, participant of various international education and research projects (e.g. Jean Monnet, Atlantis, International Visegrad Fund IVF, Central European Initiative (EI), visiting professor in various American and European universities, including Grand Valley State University (Grand Rapids, USA), Roosevelt University (Chicago, USA), University of Detroit Mercy (Detroit, USA), Loyola University Chicago (Chicago, USA), Northumbria University (Newcastle, UK), University College London (UK), Technical University of Cartagena (Cartagena, Spain), FH Joanneum (Graz, Austria).

Correspondence to: Prof. UEK dr hab. Krzysztof Wach, Cracow University of Economics, Faculty of Economics and International Relations, Department of Entrepreneurship and Innovation, 31510 Kraków, ul. Rakowicka 27, Poland, e-mail: wachk@uek.krakow.pl

\section{Liwiusz Wojciechowski}

PhD student at the Faculty of Management of the Cracow University of Economics (Poland). Master in Econometrics and Computer Sciences as well as in International Finance and Banking (University Gdańsk, Poland); Bachelor in International Trade, in Econometrics and Computer Sciences, as well as in Spatial Planning (University of Gdańsk, Poland).

Correspondence to: Mgr Liwiusz Wojciechowski, Cracow University of Economics, Faculty of Economics and International Relations, Department of Entrepreneurship and Innovation, 31510 Kraków, ul. Rakowicka 27, Poland, e-mail: liwiusz.w@o2.pl

\section{Acknowledgements and Financial Disclosure}

The article came into being within the statutory research project entitled "Entrepreneurship Education towards Contemporary Challenges" coordinated by K. Wach and financed by the Ministry of Science and Higher Education of the Republic of Poland with the funds allocated to development of research potential of the Faculty of Economics and International Relations of the Cracow University of Economics.

\section{Copyright and License}

This article is published under the terms of the Creative Commons Attribution - NonCommercial - NoDerivs (CC BY-NC-ND 3.0) License http://creativecommons.org/licenses/by-nc-nd/3.0/ 